\title{
Front Matter: Volume 7915
}

, "Front Matter: Volume 7915," Proc. SPIE 7915, High Energy/Average Power Lasers and Intense Beam Applications V, 791501 (3 March 2011); doi:

$10.1117 / 12.890184$

SPIE. Event: SPIE LASE, 2011, San Francisco, California, United States 


\section{PROCEEDINGS OF SPIE}

\section{High Energy/Average Power Lasers and Intense Beam Applications V}

Steven J. Davis

Michael C. Heaven

J. Thomas Schriempf

Editors

23 and 25 January 2011

San Francisco, California, United States

Sponsored and Published by

SPIE 
The papers included in this volume were part of the technical conference cited on the cover and title page. Papers were selected and subject to review by the editors and conference program committee. Some conference presentations may not be available for publication. The papers published in these proceedings reflect the work and thoughts of the authors and are published herein as submitted. The publisher is not responsible for the validity of the information or for any outcomes resulting from reliance thereon.

Please use the following format to cite material from this book:

Author(s), "Title of Paper," in High Energy/Average Power Lasers and Intense Beam Applications V, edited by Steven J. Davis, Michael C. Heaven, J. Thomas Schriempf, Proceedings of SPIE Vol. 7915 (SPIE, Bellingham, WA, 2011) Article CID Number.

ISSN 0277-786X

ISBN 9780819484529

Published by

SPIE

P.O. Box 10, Bellingham, Washington $98227-0010$ USA

Telephone +1 3606763290 (Pacific Time) · Fax +1 3606471445

SPIE.org

Copyright (@ 2011, Society of Photo-Optical Instrumentation Engineers

Copying of material in this book for internal or personal use, or for the internal or personal use of specific clients, beyond the fair use provisions granted by the U.S. Copyright Law is authorized by SPIE subject to payment of copying fees. The Transactional Reporting Service base fee for this volume is $\$ 18.00$ per article (or portion thereof), which should be paid directly to the Copyright Clearance Center (CCC), 222 Rosewood Drive, Danvers, MA 01923. Payment may also be made electronically through CCC Online at copyright.com. Other copying for republication, resale, advertising or promotion, or any form of systematic or multiple reproduction of any material in this book is prohibited except with permission in writing from the publisher. The CCC fee code is 0277-786X/11/\$18.00.

Printed in the United States of America.

Publication of record for individual papers is online in the SPIE Digital Library.

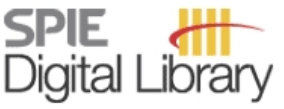

SPIEDigitalLibrary.org

Paper Numbering: Proceedings of SPIE follow an e-First publication model, with papers published first online and then in print and on CD-ROM. Papers are published as they are submitted and meet publication criteria. A unique, consistent, permanent citation identifier (CID) number is assigned to each article at the time of the first publication. Utilization of CIDs allows articles to be fully citable as soon they are published online, and connects the same identifier to all online, print, and electronic versions of the publication. SPIE uses a six-digit CID article numbering system in which:

- The first four digits correspond to the SPIE volume number.

- The last two digits indicate publication order within the volume using a Base 36 numbering system employing both numerals and letters. These two-number sets start with 00, 01, 02, 03, 04 , 05, 06, 07, 08, 09, OA, OB ... 0Z, followed by 10-1Z, 20-2Z, etc.

The CID number appears on each page of the manuscript. The complete citation is used on the first page, and an abbreviated version on subsequent pages. Numbers in the index correspond to the last two digits of the six-digit CID number. 


\section{Contents}

$\checkmark$ Conference Committee

vii Microfabrication by optical tweezers (Plenary Paper) [792102]

R. Ghadiri, T. Weigel, C. Esen, A. Ostendorf, Ruhr-Univ. Bochum (Germany)

\section{SESSION 1 COIL, EOIL}

791502 Recent electric oxygen-iodine laser experiments and modeling (Invited Paper) [7915-01]

D. L. Carroll, G. F. Benavides, J. W. Zimmerman, CU Aerospace LLC (United States);

B. S. Woodard, Univ. of Illinois at Urbana-Champaign (United States); A. D. Palla, CU Aerospace LLC (United States); M. T. Day, Univ. of Illinois at Urbana-Champaign (United States); J. T. Verdeyen, CU Aerospace LLC (United States); W. C. Solomon, Univ. of Illinois at Urbana-Champaign (United States)

791503 New concepts of the chemistry of electric-discharge oxygen-iodine lasers (Invited Paper) [7915-02]

W. T. Rawlins, S. Lee, A. J. Hicks, I. M. Konen, D. B. Oakes, E. P. Plumb, S. J. Davis, Physical Sciences Inc. (United States)

791504 Catalytic enhancement of singlet oxygen production and optical gain in electric discharge oxygen-iodine laser systems [7915-03]

S. Lee, W. T. Rawlins, A. J. Hicks, I. M. Konen, E. P. Plumb, S. J. Davis, Physical Sciences Inc. (United States)

791505 A simplified kinetic model for the COIL active medium [7915-04]

V. N. Azyazov, S. Yu. Pichugin, P.N. Lebedev Physical Institute (Russian Federation);

M. C. Heaven, Emory Univ. (United States)

\section{SESSION 2 DPAL, XPAL}

791506 Demonstration of a diode pumped continuous wave potassium laser [7915-05]

B. V. Zhdanov, M. K. Shaffer, R. J. Knize, U.S. Air Force Academy (United States)

791507 Cesium laser operating in the blue by direct optical excitation of the $7^{2} \mathrm{P}_{3 / 2}$ state [7915-06]

K. C. Brown, G. P. Perram, Air Force Institute of Technology (United States)

791508 Small signal gain in DPAL systems [7915-07]

K. L. Galbally-Kinney, D. L. Maser, W. J. Kessler, W. T. Rawlins, S. J. Davis, Physical Sciences Inc. (United States)

791509 High-energy transversely pumped alkali vapor laser [7915-08]

J. Zweiback, A. Komashko, General Atomics Aeronautical Systems, Inc. (United States) 
$79150 \mathrm{~A} \quad$ New electronic transitions of the rubidium dimer [7915-09]

J. Han, M. C. Heaven, Emory Univ. (United States)

$79150 B \quad X P A L$ modeling and theory [7915-10]

A. D. Palla, D. L. Carroll, J. T. Verdeyen, CU Aerospace LLC (United States); M. C. Heaven, Emory Univ. (United States)

\section{SESSION 3 LASER TECHNOLOGY AND APPLICATIONS}

$79150 \mathrm{O} \quad$ Energy transfer kinetics of the $n p^{5}(\mathbf{n + 1}) \mathrm{p}$ excited states of $\mathrm{Ne}$ and $\mathrm{Kr}$ [7915-13] M. H. Kabir, M. C. Heaven, Emory Univ. (United States)

7915 OF Mode-locked CO laser for isotope separation of uranium employing condensation repression [7915-14]

I. Y. Baranov, A. V. Koptev, Baltic State Technical Univ. (Russian Federation)

$79150 \mathrm{G}$ Autocorrelation of femtosecond VUV pulses using multiphoton ionization [7915-15] M. Kaku, W. Nagaya, H. Zushi, M. Katto, S. Kubodera, Univ. of Miyazaki (Japan)

Author Index 


\title{
Conference Committee
}

\author{
Symposium Chairs
}

Friedhelm Dorsch, TRUMPF GmbH \& Company KG (Germany)

Alberto Piqué, Naval Research Laboratory (United States)

Symposium Cochairs

Donald J. Harter, IMRA America, Inc. (United States)

Peter R. Herman, University of Toronto (Canada)

Program Track Chair

Gregory J. Quarles, BE Meyers \& Company Inc. (United States)

Conference Chairs

Steven J. Davis, Physical Sciences Inc. (United States)

Michael C. Heaven, Emory University (United States)

J. Thomas Schriempf, Naval Sea Systems Command (United States)

Program Committee

David L. Carroll, CU Aerospace LLC (United States)

Jarmila Kodymová, Institute of Physics of the ASCR, v.v.i. (Czech

Republic)

Timothy J. Madden, Air Force Research Laboratory (United States)

William E. McDermott, University of Denver (United States)

Wilson T. Rawlins, Physical Sciences Inc. (United States)

Session Chairs

1 COIL, EOIL

J. Thomas Schriempf, Naval Sea Systems Command (United States)

2 DPAL, XPAL

Wilson T. Rawlins, Physical Sciences Inc. (United States)

3 Laser Technology and Applications

David L. Carroll, CU Aerospace LLC (United States) 
Downloaded From: https://www.spiedigitallibrary.org/conference-proceedings-of-spie on 26 Apr 2023

Terms of Use: https://www.spiedigitallibrary.org/terms-of-use 